\title{
Identification of Jakarta Government Policy on Large Scale Social Restrictions (PSBB) COVID 19
}

\author{
Mahadiansar $^{1}$; Asrifia Ridwan ${ }^{2}$; Baiq Dewi Kamariani ${ }^{3}$; Fannidya Hamdani Zeho ${ }^{4}$ \\ ${ }^{1}$ Universitas Brawijaya, mahadiansar@student.ub.ac.id \\ ${ }^{2}$ Universitas Brawijaya, asrifia.ridwan@gmail.com \\ ${ }^{3}$ Universitas Brawijaya, baiqdewikamariani95@gmail.com \\ ${ }^{4}$ Universitas Brawijaya, fannidyazeho@student.ub.ac.id
}

\begin{abstract}
Abstrak
Penerapan Pembatasan Sosial Berskala Besar (PSBB) membuat kebijakan pemerintah DKI jakarta mendapatkan respon dari warga DKI Jakarta serta pemangku kepentingan dalam menurunkan angka penyebaran COVID-19 di DKI Jakarta. Tujuan dari penelitian ini untuk mengidentifikasi kebijakan pada implementasi penerapan PSBB DKI Jakarta mengunakan teori grindle dengan faktor komunikasi, faktor sumberdaya manusia, faktor sikap pelaksana dan faktor struktur birokrasi dengan menguraikan proses implementasi kebijakan tersebut. Adapun metode penelitian mengunakan data sekunder kualitatif berfokus pada analisis data dengan pencocokan pola dan mengembangkan penjelasan penelitian. Temuan menunjukan bahwa dari emapt faktor tersebut pada implementasinya sudah berjalan dengan baik, namun dari faktor sikap pelaksana pada hasil implementasi kebijakan menunjukan kurang baik dikarenakan angka kasus COVID-19 di DKI Jakarta masih tergolong tinggi dari presentase yang di lakukan pemerintah DKI Jakarta. Dengan demikian perlunya optimalisasi disposisi atau sikap pelaksana dalam melibatkan para ahli agar angka kasus COVID-19 menurun pada penyebaran pandemi COVID-19 di DKI Jakarta
\end{abstract}

Kata kunci : COVID-19, Implementasi, Pemerintah DKI Jakarta, PSBB

\begin{abstract}
The application of Large Scale Social Restriction (PSBB) makes the policy of the government of DKI Jakarta to get a response from the citizens of DKI Jakarta as well as stakeholders in the lower figure of the spread COVID-19 in DKI Jakarta. The purpose of this research is to identify the policy on the implementation of the PSBB DKI Jakarta using the theory of grindle with communication factors, factors of human resources, factors of attitudes, and factors of the bureaucratic structure by outlining the process of implementation of the policy. The research method using secondary data qualitative focuses on the analysis of data with matching patterns and develop explanations of the study. The findings showed that of the four factors on the implementation has been running well, but from the factor of the attitude of the on the results of the implementation of the policy showed less good because the number of cases COVID-19 in DKI Jakarta is still relatively higher than the percentage do the government of DKI Jakarta. Thus the need for optimization of the disposition or attitude of implementers in involving experts in order cases COVID-19 decrease on the spread of the pandemic COVID-19 in DKI Jakarta
\end{abstract}

Keywords : COVID-19, Government of DKI Jakarta,Implementation, PSBB 


\section{Introduction}

The World organization the World Health Organization (WHO) claims that the coronavirus disease 2019 or abbreviated COVID-19 as a pandemic that is not to be underestimated, many Countries in the world issuing an alternative policy as an attempt to inhibit the rate of spread of the virus on a massive scale. It cannot be denied that this plague has managed to make a record rate of growth of death becomes very high with the number of confirmation 14.971 .036 positive cases COVID-19 including 618.017 deaths reported to WHO as of 23 December 2020. Almost in every field, the government issued a policy of considering the impact of the COVID-19 very large effect on all human activity including the to limit the activity of the man himself outside the house. Lock all access or lockdown be the choice of some Countries such as China, Italy, France, and some other countries. But some Countries also do not apply lockdown because on the other hand will complicate the economic activity of the Country.

Indonesia is one of the Countries that do not apply lockdown but the alternative to the policy conducted by the Indonesian is to apply Restrictions on Large-Scale Social (PSBB) in some zones a certain area (Andriani, 2020). According to the Regulation of the Minister of Health of the Republic of Indonesia Number 9 the Year 2020 on Guidelines for the PSBB in Order to accelerate the Handling of COVID-19 mentioned in article 1 ob Large Scale Social Restrictions (PSBB) is the restriction of certain activities of the population in a region suspected of being infected COVID-19 in such a way as to prevent the possibility of spread. PSBB is a term health quarantine in Indonesia, which is defined as "the Restriction of certain activities of the population in a region suspected of being infected of the disease and/or contaminated in such a way as to prevent the possible spread of disease or contamination. PSBB is one type of implementation of health quarantine in the region, in addition to the quarantine house, the quarantine hospital, and the quarantine region.

The purpose of PSBB, namely to prevent the spread of disease emergencies of public health that is happening between people in a particular region. Restrictions on the activities carried out most little covers to close the school 
and place of work, restriction of religious activities, and/or the restriction of activities on-site or public facilities. PSBB did by the provincial governments and district/city after obtaining approval from the Health Minister through the Decision of the Minister. In this case, the Government of DKI Jakarta Province become one of the areas that implement the policy PSBB longest when compared with other regions in Indonesia. the absence of regulation of the PSBB can be adhered to by the citizens of the state because as we all know that the threat of COVID 19 this is a threat that is actually real and not looked at the bottom to the top though (Nasruddin \& Haq, 2020)

The attention of the government in Jakarta is very great to extend the period of PSBB because the calculation according to the data Taskforce of Acceleration Handling COVID-19 numbers have been confirmed positive COVID19 in DKI Jakarta as of 23 July 2020 as much as 18.545 or $19.2 \%$ of the soul. Through the Governor regulation of DKI Jakarta Number 33 the Year 2020 the implementation of the PSBB may include activity restrictions on the outside of the house with restrictions on the implementation of the learning schools or other educational institutions, the restriction of work activity in the workplace, restrictions on religious activities in houses of worship, restrictions on the activities on the premises or public facilities, restrictions on social and cultural activities as well as restrictions on the movement of people and goods using the transportation mode.

The enforcement of the PSBB has implications on the citizens of DKI Jakarta have restrictions on outside activities and trigger the occurrence of economic losses. Hadiwardoyo (2020) reveal that the losses of individuals and businesses are the implication that most felt due to the enforcement of the PSBB. For business entities that lead to the loss of revenue because of no sales, the onset of damage to the goods as well as expenses is increasing for the payment of fines or the cost of severance pay do a termination until the assets of the company which is to be cheap. While for the individual causing the loss of salary or benefits during times of crisis, occurs most fines due to liability late payment penalties or interest, 
extra expenses for families in emergency conditions even cause loss of job due to termination of employment.

The Provincial Government of DKI Jakarta recorded as many as 6.785 companies doing the Termination of the Employment Relationship with the amount of labor as much as 50.891 people. Meanwhile, on the other hand there are 32.882 companies are laying off employees by the number of 272.333 people (Defianti, 2020). The true policy of the PSBB provides a great consequences to changes in the standard of living of every human being. The economic crisis becomes a crucial issue that has implications for fulfilling the needs of the community demanded the presence of an alternative policy solution. One of them is a modification of the program Card Prakerja as the spring of social assistance that the majority of the content is financial incentives because of termination of employment to be able to survive during a pandemic (Maharani, 2020). However, it only lasts short term and not commensurate with the consequences of termination of the employment relationship that result in long-term for the people of Jakarta.

In empirics, the organization will determine the performance impact in a program to be better or worse to determine policy in the future (Yudiatmaja, 2016; Yudithia \& Mahadiansar, 2019). Need to be observed that the policy of the PSBB does not fully provide the bad consequences of the condition of DKI Jakarta. The priority of the implementation of the protocol of health on a large-scale makes a positive contribution to minimizing the spread of COVID-19. Best practices for the achievement of the policy PSBB can be reflected from the cooperation between the parties and sanctions for violators in the enforcement of the rules. Good cooperation between the parties supported in the efforts to achieve the termination of the chain COVID-19 through the closure of some activity outside the home such as closing the center of the crowd, the school, doing the protocol even the health system work from home. Meanwhile, the strict punishment of offenders PSBB set out in Governor Regulation of DKI Jakarta Number 412020 expressly provides for fines and even criminal sanctions for violators of the PSBB.

Sanctions are expressly set by the government giving the meaning so that the people of Jakarta being obedient to the suggestion in the house of course. The 
recommendation will remain in the home or stay at home can slow down the transmission of covid-19 and reduce the number of epidemics that can potentially meet the health service (Setiati \& Azwar, 2020). The prevention of pandemic COVID-19 as early as possible should continue to be done including carrying out the policy of the PSBB. PSBB is part of the emergency response health aimed at the prevention of the expansion of the spread of the disease that occurs between people in a particular area which today is called COVID-19, implementation of the PSBB is not only done by the government alone but needs to be coordination and cooperation between the various parties in accordance with the applicable provisions (Hairi, 2020). The implementation of the policy of PSBB is also described in article 59 of the LAW of health quarantine set up that the PSBB most bit set: a) school holidays and the workplace, b) the restriction of religious activities, c) the restriction of activities on-site or public facilities. In the application of the policy PSBB, the most important thing is for the government and the public alike to work together in the effort of handling COVID-19.

The implementation of the policy PSBB in DKI in the success of the implementation of the PSBB in DKI Jakarta, where State officials and public officials need to understand the concept and implementation of the basic law of the policy PSBB, Need to have the unity of perspective in implementing the policy PSBB such as social and physical distancing, hand washing using soap, stay at home, use a mask when out of the house, and not do the crowd (Fauzi, 2020). The presence of one command in policy implementation in PSBB in accordance with the implementation of the policy PSBB in DKI Jakarta declared successful viewed from some things including the readiness of public officials in dealing with the spread of the plague, means of support, the availability of fees, coordination with the parties involved and the sanctions given to violators of the policy.

However, based on the exposure of the commissioner of the national human RIGHTS Commission Mohammad Choirul anam that the success of the application of PSBB in DKI Jakarta has reached $60 \%$. Things that become obstacles in the success of the PSBB in Jakarta because there are still many people passing or traveling on the road, the community is not yet fully obedient to remain 
at home and not travel unless the sector obtained in the PSBB and the unstable economy of the community. The application of PSBB in DKI can have an impact on the decrease of cases covid-19. This is evident from the proportion of positive cases in DKI with the case nationally. Where DKI on April 5, cases confirmed positive by as much as $50 \%$ of the total cases nationwide. After PSBB on march 5, decrease the number of a confirmed case of DKI Jakarta Province to $39 \%$ of the total cases Nationwide (Hakim, 2020)

Although basically the government imposition of PSBB in order to cope with the pandemic COVID-19 as a form of health protection for the community but can result in an economic downturn for the majority of the people of Indonesia, especially Jakarta. although data on cases COVID-19 decreased as a result of the enforcement of the PSBB the economic impact is felt by the community, where a lot of business activity that suddenly stops, the trader earned a little more than usual. The business activities of both individuals and families, institutions and the state can no longer perform activities, and operations are normal. Restaurants, malls, hotels, and tourist attractions cannot operate, trading deserted, stay a little, and of course many were harmed, especially the trader and the company.

From the problems above result in the workers or marketing personnel can not meet the sales target so as to avoid greater losses the company made termination of employment. Then the workers and ordinary traders while at home which resulted in no longer have an income and a reduced income. Based on a discourse regarding the identification of policy, many researchers identify the policy on its implementation is both descriptively and statistically (Hikmahwati et al., 2020). The Model of implementation developed by Edward (1980) more familiar with the term direct and indirect impact of implementation.

In the approach (Edward, 1980), there are four variables that determine the success of a policy that consists of 4 factors, including Communication, Resources, Disposition, and Bureaucratic Structures. This Model is a portrait of the general that the implementation of the policy runs in a linear manner from communication, political resources that are available and the implementation of the policy implementation. 


\section{Framework 1. Model the Implementation of Public Policy Edward III}

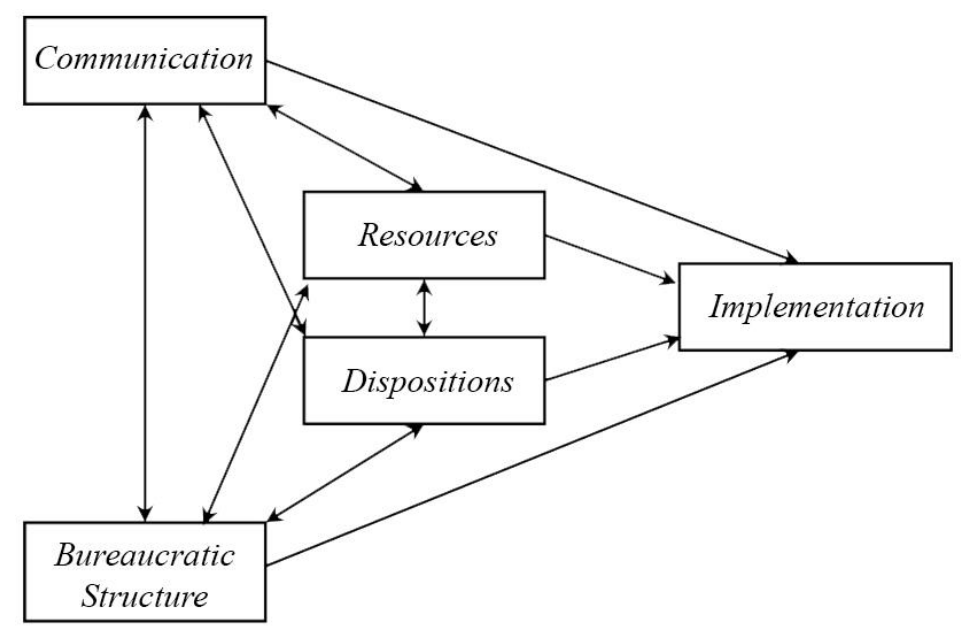

Source : Edward (1980)

The application of PSBB have an impact on the declining rate of cases COVID-19 but not on the economic growth of the community, Where business activities stop due to the application of PSBB create income to the company faltered when the company must pay the operational costs of the employees which impact on the dismissal of workers or termination of employment (Sufiarina \& Wahyuni, 2020). However, this policy can be seen factors influence the amount of human resources are still lacking so that it can inhibit the speed in the provision of information (Suryaningsih et al., 2019). Based on the number of disputes both in the level of human resources as well as the provision of information by the application of the policy of PSBB, which have been implemented. Therefore it is necessary to Identify the Policy of the Government of DKI Jakarta in the Implementation of Social Restrictions Large-Scale Handling (PSBB) COVID-19.

\section{Method}

Research methods using literature study qualitative outlines the identification of the occurrence of the implementation of the policy PSBB by the Government of DKI Jakarta. The research literature examines the secondary data to perform a search against multiple sources such as e-book, Journal, Website, Report Organization and other documents, both print and online relevant (Zed, 2014). The identification of the policy will focus on measures of the occurrence of the policy 
of the Government of DKI Jakarta in the implementation of PSBB in handling COVID-19 using the theory of Edward (1980). Furthermore, researchers focusing on analysis of research data with matching patterns and develop explanations research (Yin, 2015) on the identification of policy application of PSBB in handling COVID 19 DKI Jakarta.

\section{Results and Discussion}

\section{PSBB Program initiation of the Government of DKI Jakarta}

The implementation of the program PSBB in DKI Jakarta has at least eight sectors refer to the regulations of the governor that gets the exception as much as 8 sectors consist of Health; Food, food and drink Sector; energy, water, gas, and petrol station; the communication Sector, better communication services to the communications media; the financial and banking sector, including capital market Sector; the logistics of distribution of goods; Sector related to the needs of daily life and retail such as cafes, grocery stores; and industrial Sector located in the capital city. The health sector is referred to as a hospital or clinic. It belongs to the healthcare industry that produces soap, disinfectants, and others related to the treatment of coronavirus. However, the sectors excluded have to follow the procedure fixed handling COVID-19, such as requiring the use of masks and facilities hand-washing.

There are 105 Markets continue to Operate with the aim that as many as 105 markets are prepared in Jakarta during the application of the PSBB is in particular related to the needs of the community, providing Market facilities for shopping long distance in 105 markets in Jakarta. The provision of the market to meet the needs of the citizens of the capital can be done through remote transactions during their day at home. In addition, the private one president Director of PT Food Station Tjipinang Jaya will utilize site-buy online and delivery services to facilitate services to consumers so they can shop from home. The whole product is Food Station marketed with reference to the selling prices that applied to the Ministry of Commerce. In addition, it facilitates the outlet Perumda Pasar Jaya through Jakgrosir up to strategic partners of PT Food Station in Jakarta. The Outlet provides 
a number of goods shopping needs groceries that can be purchased by consumers from home.

The poor will be assisted by the government of DKI Jakarta to ensure both economies of the poor and vulnerable poor will be assisted. the government of DKI Jakarta issued by 3.7 million poor families and vulnerable poor in Jakarta will get a live help of 1 million per family per month. Assistance was given for 2 months. The Total funds required to Rp7.4 trillion. The burden of social assistance this will be divided into two, namely from Jakarta city budget for 1.1 million poor families who have received program assistance from the Provincial Government of DKI Jakarta, while the central government help 4,567 trillion for 2 months, or about 800 thousand per family to 2.6 million families. Furthermore, marriage and circumcision are permitted not prohibited even though one of its provisions is the banning of the activities of the crowd. On socio-cultural activities, especially weddings and circumcisions can be done with these terms. Activities-the activities of the social rituals of the culture it can be done without any celebration. During the PSBB progresses there will be penalties applied for the violation.

Furthermore, public transport in the limit, and private vehicles smoke with a note, this shows the PSBB will only be valid for the whole public transport. In the meantime, to run the rules of social distancing, the capacity of passengers for all public transport in Jakarta will be down 50 percent. Then on the taxi online is still allowed to carry passengers when the application of PSBB. However, there are some notes for taxi drivers online about the rules of carrying passengers while the application of PSBB in Jakarta. Regarding the fate of the drivers online are only allowed to activities send the goods only when the application of PSBB Jakarta and a crowd of 5 People are forbidden. The government and the relevant authorities will take decisive action and ensure that all the provisions of the PSBB were followed by the community. Later, he explained, there will be a patrol tight. The step was taken for the common good in an effort to prevent the spread of the virus corona or COVID-19. The government of DKI Jakarta along with law enforcement will do all the steps firmly. 


\section{Identification of Policy Implementation Models the Theory of Edward III}

\section{a. Communication}

Communication is a tool in the conduct of social interaction in the life that aims to identify and estimate between each other, in addition, communication is also present to create an atmosphere of balance in conveying an idea and the idea that there is delivered to the other party (Berlo, 1960). The implementation of public policy is the effort of a public policy process that is very important. In the case of the application of PSBB in DKI Jakarta, the many stakeholders involved to provide information to the citizens of Jakarta will be the importance of the application of PSBB, ranging from dissemination either through the media or appeals directly with the keep protocol health.

In order to prepare themselves to face the pandemic COVID-19 in accordance with the Governor Regulation of DKI Jakarta Number 33 the Year 2020 On the Implementation of the PSBB in the Handling of the COVID-19 in DKI Jakarta. The implementation of the policy part of the reality of the real to strengthen good relations of all stakeholders ranging from coordination up to the realization that with the Regulation of the Governor, all stakeholders will disseminate on a large scale in the implementation of policies application of PSBB in DKI Jakarta.

Communication in organization is a process that is very complex and complicated. A person can hold it only for a particular purpose, or redistribute it. In addition, distinct sources of information will also give birth to different interpretations anyway. So the implementation goes effectively, who is responsible for carrying out a decision must know whether they can do it (Syani et al., 2017) an outline of the achievements of the great success in communication will be the factors that affect them:

1. Socialization; For the success of the application of PSBB in DKI Jakarta, the Provincial government of DKI Jakarta involving stakeholders one of the officer's Police Unit (SATPOL PP) Civil service, in addition, the necessity also the level of public awareness of the importance of the application of PSBB to reduce the spread of COVID 19. This makes the socialization that is implemented to be efficient and effective for community participation. 
2. Transparency; Program implementation PSBB in DKI Jakarta should be described in the society by way of communications explained that the appeal was based on Governor Regulation of DKI Jakarta Number 33 the Year 2020 On the Implementation of the PSBB in the Handling of the COVID-19 in the Province of DKI Jakarta.

3. Consistent and Sustainable; the Government of DKI Jakarta will do an evaluation on the socialization of the application of PSBB DKI Jakarta in order to reach the category of efficiency and effectiveness of the policy that has been made is certainly not going to stop socializing at all, but should be continuous socialization of the application of PSBB DKI Jakarta in order not to the occurrence of the error information at the time of PSBB done.

\section{b. Human Resources}

The source of power is a system design-formal systems in an organization to ensure the use of talent and human potential effectively and efficiently in order to achieve the goals of the organization (Mathis \& Jackson, 2010). The issue of resources should be adequate especially human resources are the most important includes staff with the size or the number of sufficient and proper with the necessary expertise; in addition, it is associated with authority and facilities.

Activities in the scope of human resource development aims to improve and develop the human resource capacity that has been owned, so it will not be left behind by the development of the organization as well as science of the social, economic, technological and cultural has become the obligation and authority to contribute to the nation and the state (Kurnianingsih et al., 2017)

Based on the program PSBB organized by the government of DKI Jakarta shows that the Government of DKI Jakarta is capable and ready to implement the policy program of the PSBB. The readiness and ability of the government of DKI Jakarta can be seen among :

1. The experience of the government of DKI Jakarta in the emergency response will be a pandemic COVID-19 already predicted the spread will be greater, therefore the government of DKI Jakarta has been preparing agendas to save the health of the citizens of Jakarta. 
2. Elements of the government of DKI Jakarta is very adequate because it is filled in accordance with the capacity of professionalism by involving stakeholders.

3. The liveliness of a community or non-governmental organizations in the private sector strongly supports and contributes to its involvement in the application of PSBB in DKI Jakarta.

Nevertheless from the side of the resource good, still also get the counter will be the application of PSBB with the expense of the economy of the people in DKI Jakarta but anticipate that cons would PSBB, the government has also prepared a policy alternative to how human resources both from government and private sector can participate with the innovation in the addition of the program PSBB. Please be aware that PSBB is in compliance with the Regulations of the Governor of DKI Jakarta No. 33 the Year 2020 On the Implementation of the PSBB in the Handling of the COVID-19 in DKI Jakarta.

\section{c. The disposition or Attitude of Implementers}

The disposition or attitude of implementers of policy can be seen through the understanding and deepening, the direction of the policy response, the intensity of the policy, if the implementation is to be effective then the executor is not only knowing what will be done but also must have the ability to carry it out. This disposition is the willingness, the desire, and the tendency of the attitude of the implementers to carry out in earnest so that what becomes the goal can be realized. This disposition will appear among the executive, so that benefitted not only his organization but also the self attitude to implementing them. Knowledge, deepening, and understanding will lead to the attitude received, indifferent, and refuse to policy (Akib, 2010).

The attitude of accepting, indifferent, and refusing will cause disposition in self-implementing the policy and the disposition of the high impact on the success of the implementation of the policy. An understanding of the intent of the standards and policy objectives is important because of a high understanding of policy implementation that can successfully so fail when implementers are not fully aware of the standards and objectives of the policy. On the contrary, if the executor 
of the spread and depth of the standards and objectives among those responsible for implementing the policy is a huge potential to the success of the implementation of the policy (Edward, 1980).

The behavior, the attitude of the implementor, and the disposition of the supervisor must know what should be done and have the capacity to do it. the tendency of the executive has important consequences for effective policy implementation. According to Edward III, this disposition is the willingness, the desire, and the tendency of policy actors and to implement policies was seriously so what becomes of the policy objectives can be realized Associated with the concept about the disposition or attitude of implementers in the implementation of a policy.

Based on the above explanation that the policy of the government of DKI Jakarta to implement PSBB in the field of the factors of the disposition (attitudes) in the implementation is good because the figures show a decline since the PSBB implemented. The government of DKI Jakarta's commitment and participation will the stakeholders (BNPB, Community, non-Governmental organizations, Law enforcement agencies, private companies) in the conduct of the appeal in a transparent manner will be the importance of the Jakarta residents know the PSBB. Because the stakeholders by involving all of society will feel the benefits to prevent the spread of COVID-19 in DKI Jakarta. Here is a chart in the form of secondary data was done by a team of epidemiologists.

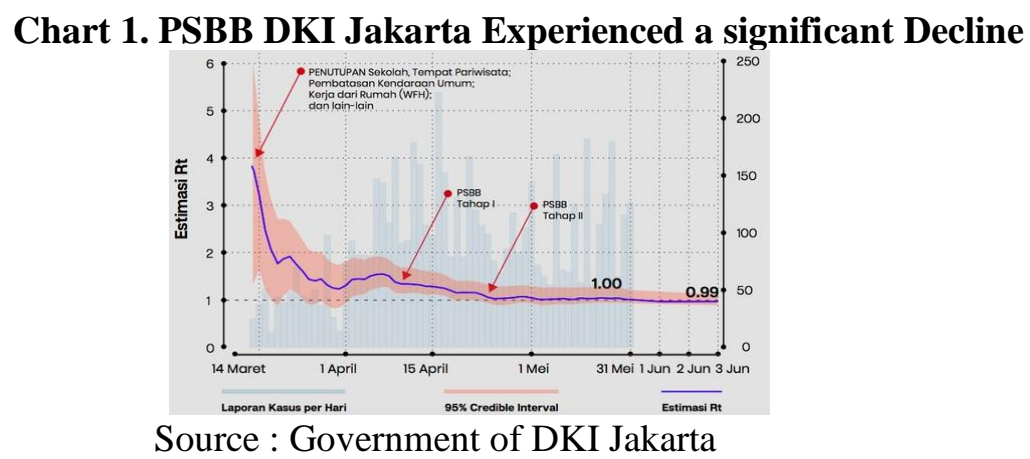

Based on the chart which is owned by the government of DKI Jakarta shows that the imposition of PSBB from the first stage to the second stage which 
was held on March 14, 2020, until April 10, 2020, decreases the rate of transmission (estimated RT) COVID-19. It is delivered directly by the governor of DKI Jakarta, Anies Rasyid Baswedan.

"The first is the status of RT per day, to 0.99, but we're moving rather long in the month of March, the figure (RT) we about 4. Then we do the restrictions, closure of schools, tourist attractions, carfree day, office-office, calls for work on the house began in midMarch. And what happened? Experienced a very drastic decline. This is done before the PSBB. So when PSBB the first phase began on 10 April, then the second stage also we go on, figure that the most drastic fall is in the months of March and April, this means that the entire working population of Jakarta"

However, in the case of trains researchers analyzed have not shown the balance in the decrease in cases COVID-19, which needs to be evaluated on the factors attitudes by showing the task as well as the rights and authority of the task force for the acceleration of handling COVID-19 in DKI Jakarta. The importance of the reform of the executive both on the task force handling COVID-19 or a team of experts handling COVID-19 must have a strength in action strategic. In his article asserting the interests of improving the performance of the disposition or the attitude of the ideal in handling in the health sector. Improve the performance of the disposition or attitude of implementers must have synchronization between the implementation of the PSBB and the number of cases each day in DKI Jakarta although the rate of transmission COVID-19 decreased significantly.

\section{d. The Structure Of Bureaucracy}

A form of organization that its application is associated with objectives to be achieved. Bureaucracy is intended as a system of authority set forth in a rational way by a wide variety of regulations to organize the work done by many people (Andreski, 1989). the organization must be structured clearly. the principle associated with the work procedures and the size of the effect, hierarchies organizational structure, coordination, decentralization, and authority. Understanding the bureaucratic structure or organization can be defined as a pattern of authority relations and coordination between the implementing agency (agencies) associated with the implementor of the policy. 
On the structure of the organization, handling COVID-19 in DKI Jakarta in the implementation of PSBB, it can be concluded that already the establishment of good coordination and cooperation on every element of the stakeholders, both from the province of DKI Jakarta, law enforcement agency, the district to the Pillars of the Neighbors and Pillars of Citizens in DKI Jakarta. Each of these elements, already coordinate with each other and perform the function and their respective roles so well that there are no constraints which mean starting from the preparation of the concept on implementation of PSBB, so also from the house of Representatives of DKI Jakarta, which oversees the implementation of the PSBB everything that is done by the Government of DKI Jakarta so that there is no misunderstanding in every element of the stakeholders in the implementation of the PSBB DKI Jakarta.

\section{Conclusion}

The government of DKI Jakarta in principle has been prepared from the concept to the implementation in the implementation of the policy PSBB in the face of the pandemic COVID-19 in accordance with the conditions very concerning for the sake of saving the lives of the people of Jakarta. Supporting factors in the implementation of the PSBB that includes: rules that support from the central government through the ministry of health of the Republic of Indonesia, the government of Indonesia based Jakarta so that the spread of the pandemic COVID19 potentially very large so the implementation of the policy PSBB already in place with pay attention to the economy of the citizens of Jakarta. Further inhibiting factors on the implementation of the policy application of PSBB is still lack of participation of the community in a number of cases COVID-19 according to the previous explanation. Although in the category of deployment COVID-19 shows the low from time to time that has been described on the factors of the disposition or attitude of implementers. 


\section{Reference}

Akib, H. (2010). Implementasi kebijakan: Apa, mengapa dan bagaimana. Jurnal Administrasi Publik, 1(1), 1-12.

Andreski, S. (1989). Max Weber: kapitalisme, birokrasi, dan agama (H. Hadikusumo, Ed.; 2nd ed.). Tiara Wacana Yogya.

Andriani, H. (2020). Effectiveness of Large-Scale Social Restrictions (PSBB) toward the new normal era during COVID-19 Outbreak: a mini policy review. Journal of Indonesian Health Policy and Administration, 5(2), $61-65$.

Berlo, D. K. (1960). The process of communication: An introduction to theory and practice. Holt, Rinehart and Winston.

Defianti, I. (2020). Pemprov DKI: 50.891 pekerja kena PHK dan 272.333 $\begin{array}{llll}\text { dirumahkan } & \text { akibat } & \text { Covid-19. }\end{array}$ https://www.liputan6.com/news/read/4253825/pemprov-dki-50891pekerja-kena-phk-dan-272333-dirumahkan-akibat-covid-19

Edward, G. (1980). Implementing Public Policy. Congressional Quarterly Press.

Fauzi, A. (2020). Implementasi Pembatasan Sosial Berskala Besar, Sebuah kebijakan publik dalam penanganan Pandemi COVID-19. JIANA: Jurnal Ilmu Administrasi Negara, 16(1), 174-178.

Hadiwardoyo, W. (2020). Kerugian ekonomi nasional akibat pandemi COVID-19. BASKARA : Journal of Business \& Entrepreneurship, 2(2), 83-92. https://doi.org/10.24853/baskara.2.2.83-92

Hairi, J. H. (2020). Implikasi hukum Pembatasan Sosial Berskala Besar terkait pencegahan COVID-19. INFO Singkat : Kajian Singkat Terhadap Isu Aktual Dan Strategis, 12(7), 1-4.

Hakim, N. R. (2020). Doni Monardo : Dampak PSBB, Kasus Positif Covid-19 di DKI Menurun. KOMPAS. Di akses pada 28 oktober 2020 https://nasional.kompas.com/read/2020/05/11/13515621/donimonardo-dampak-psbb-kasus-positif-covid-19-di-dki-menurun

Hikmahwati, H., Sangadji, E., \& Utami, R. R. M. (2020). Impact Analysis of the Large-Scale Social Restrictions (PSBB) Policy Implementation in 
Jakarta. Journal of Indonesian Health Policy and Administration, 5(2), $57-60$.

Kurnianingsih, F., Edison, E., \& Safitri, D. P. (2017). Manajemen Sumber daya Manusia. UMRAH Press.

Maharani, T. (2020). Tenaga Ahli KSP Sebut Mitra dan Pelatihan Kartu Prakerja Bisa Dievaluasi Halaman all - Kompas.com. KOMPAS. Di akses 28 oktober 2020 https://nasional.kompas.com/read/2020/05/07/11424091/tenaga-ahliksp-sebut-mitra-dan-pelatihan-kartu-prakerja-bisa-dievaluasi?page=all

Mathis, R. L., \& Jackson, J. H. (2010). Human resource management (13th ed.).

Nasruddin, R., \& Haq, I. (2020). Pembatasan Sosial Berskala Besar (PSBB) dan Masyarakat Berpenghasilan Rendah. SALAM: Jurnal Sosial Dan Budaya Syar-i, 7(7). https://doi.org/10.15408/sjsbs.v7i7.15569

Setiati, S., \& Azwar, M. K. (2020). COVID-19 and Indonesia. Acta Medica Indonesiana, 52(1), 84-89.

Sufiarina, \& Wahyuni, S. (2020). Force majeure dan notoir feiten atas kebijakan PSBB COVID-19. Jurnal Hukum Sasana, 6(1), 1-15. https://doi.org/10.31599/sasana.v6i1.209

Suryaningsih, Y., Sartono, S., \& Jaya, A. (2019). Faktor-faktor yang mempengaruhi implementasi SIMSETGIS (Sistem Informasi Manajemen Aset Berbasis WebGIS (Geographics Information System) di badan pengelolah keuangan dan aset daerah Kota Kendari. NeoRespublica : Jurnal Ilmu Pemerintahan, 1(1), 10-22.

Syani, A. K., Mufid, S., \& Hazin, M. (2017). Komunikasi dalam implementasi lebijakan pendidikan wajib belajar 9 Tahun di Kecamatan Ngadiluwih. Khazanah Pendidikan: Jurnal Ilmiah Kependidikan, 9(1), 25-38.

The government of Indonesia (2018), Legislation Number 62018 on Health Quarantine. Jakarta: Ministry Of State Secretariat Republic Of Indonesia 
The government of Indonesia (2020), Government Regulation Number 21 the Year 2020 about Social Restrictions Large-Scale in order to accelerate the Handling of Corona Virus Disease in 2019 (COVID-19). Jakarta

The Ministry of Health of the Republic of Indonesia (2020), the Regulation of the Minister of Health of the Republic of Indonesia Number 9 the Year 2020 on Guidelines for Restrictions on Large-Scale Social in Order to accelerate the Handling of Coronavirus Disease 2019 (COVID-19). Jakarta: Ministry Of Health Of The Republic Of Indonesia

Yin, R. K. (2015). Case study research: Design and methods (5th ed.). Sage Publication.

Yudiatmaja, W. E. (2016). Implementasi dan evaluasi kebijakan publik. UMRAH Press.

Yudithia, Y., \& Mahadiansar, M. (2019). Perilaku organisasi positif dalam kinerja; Sebuah konsep dan teori. UMRAH Press.

Zed, M. (2014). Metode penelitian kepustakaan (3rd ed.). Yayasan Obor Indonesia. 